\title{
ПІДГОТОВКА ВИКЛАДАЧІВ АГРАРНИХ ВНЗ ДО ДІАЛОГІЗАЦІї ПЕДАГОГІЧНОГО ПРОЦЕСУ
}

У статті розглянуто питання навчання на діалогічних засадах та підготовки до нього викладачів аграрних ВНЗ. Доведено, шуо застосування діалогу в навчальній роботі залежить від готовності до нього викладачів як однієї із основних ланок педагогічного прочесу. Запропоновано програму психолого-педагогічного семінару для викладачів аграрних ВНЗ «Діалог у навчанні».

Ключові слова: діалогізачія, навчальний діалог, педагогічний прочес, викладач, готовність.

В статье рассматривается вопрос обучения на диалогических началах и подготовки к нему преподавателей аграрньх вузов. Доказано, что применение диалога в учебной работе зависит от готовности к нему преподавателей как одного из основных звеньев педагогического прочесса. Предложена программа психолого-педагогического семинара для преподавателей аграрных вузов «Диалог в обучении».

Ключевые слова: диалогизачия, учебный диалог, педагогический прочесс, преподаватель, готовность.

The article discusses the principles of dialogic learning and training of teachers of agricultural universites. It is proved that the use of dialogue in the classroom depends on the willingness of teachers as one of the main parts of the educational process. A program of psychological and pedagogical workshops for teachers of agricultural universites «Dialogue in teaching» is proposed.

Key words: dialogization, educational dialogue, teaching process, teacher, willingness.

Професійне спілкування у будь-якій сфері $є$ насамперед діалогічним, оскільки справжні рівноправні партнерські відносини у професійному спілкуванні можливі лише за умови діалогічної взаємодії.

За останні роки значно зросла увага до використання діалогу в навчанні, де він розглядається як «форма педагогічної взаємодії учителя - учня (учня - учня) в умовах навчальної ситуації, де відбувається інформаційний обмін, взаємний вплив і регулюються відносини» $[2$, с. 96]. Спираючись на наведене визначення діалогу, запропоноване С. Гончаренком, розглядаємо навчальний діалог як взаємодію між суб'єктами навчально-виховного процесу, яка відбувається в мотиваційній, пізнавальній, діяльнісній, почуттєвій і комунікативній сферах. М. Кларін розглядав діалог у контексті спільної навчальної діяльності вчителів і учнів, уважаючи його важливим складником навчального процесу [3]. Г. Ковальов виходить із того, що сутність психічної організації людини є діалогічною [4, с. 115]. Він уважає, що психологічною умовою реалізації розвивальної стратегії впливу, найбільш релевантної для суб'єкт-суб'єктного підходу, є діалог. Спираючись на тезу про діалогічність внутрішнього світу особистості фахівця, до основних принципів організації професійного діалогічного спілкування відносимо:

- емоційну й особистісну відкритість партнерів по спілкуванню;

- психологічну налаштованість на актуальні стани один одного;

- безоцінність, довіру і щирість висловлення почуттів і станів.

Mema cmammi - розглянути питання навчання на діалогічних засадах та підготовки до нього викладачів аграрних ВНЗ.

Підготовка викладачів до навчального діалогу стає одним із нагальних завдань при проведенні реорганізації вищої школи, про що свідчать численні публікації останніх років. У працях провідних вітчизняних учених і педагогів-практиків підкреслюється необхідність розв'язання та актуальність цієї проблеми. І. Зязюн, Л. Крамущенко, І. Кривонос, О. Мирошник, В. Семиченко, Н. Тарасевич включають діалогічність до переліку критеріїв майстерності педагога: «Критеріями майстерності педагога $є$ доцільність (за спрямованістю), продуктивність (за результатами), діалогічність (за характером стосунків з учнями), оптимальність у виборі засобів, творчість (за змістом діяльності)» $[5$, с. 34].

I. Зязюн та інші науковці виокремлюють кілька рівнів педагогічної майстерності та характеризують їх, ураховуючи уміння організувати діалог і характер взаємодії у спілкуванні. Елементарний рівень. У вчителя наявні лише окремі якості професійної діяльності. Проте через відсутність спрямованості на розвиток учня, техніки організації діалогу продуктивність його навчально-виховної діяльності є невисокою. Базовий рівень. Учитель володіє основами педагогічної майстерності: педагогічні дії гуманістично зорієнтовані, стосунки з учнями і колегами розвиваються на позитивній основі. Досконалий рівень. Характеризується чіткою спрямованістю дій учителя, їх високою якістю, діалогічною взаємодією у спілкуванні. Творчий рівень. Учитель самостійно конструює оригінальні, педагогічно доцільні прийоми взаємодії [5, с. 35].

Спираючись на вище вказану характеристику рівнів педагогічної майстерності викладачів, у своєму дослідженні виходимо з того, що для підвищення рівня педагогічної майстерності викладачі мають оволодіти уміннями організації ефективної діалогічної взаємодії на заняттях. У такому навчальному процесі, як зазначає А. Вербицький, «навчання не замикається саме на собі - навчатися, щоб отримати знання, - а є тією формою особистісної активності, яка забезпечує виховання 
необхідних предметно-професійних i соціальних якостей особистості фахівця» [1, с. 32], а це завдання, у свою чергу, зумовлює необхідність проведення внутрішньовишівської підготовки викладачів до навчального діалогу.

Для організації роботи 3 викладачами звернулися насамперед до результатів пілотного дослідження, які виявили у викладачів аграрних ВНЗ брак психолого-педагогічних знань про професійне спілкування і його культуру, засвідчили стійке прагнення викладачів до домінування на заняттях, показали побоювання багатьох із них відійти від традиційних форм навчання.

Анкетування й опитування, проведені під час дослідження, свідчать про те, що переважна більшість викладачів (76,3\%, тобто 58 із 76 респондентів) схиляється до використання традиційних форм навчання, керуючись при цьому різними причинами: браком часу; необхідністю викласти програму і побоюванням відступити від неї; небажанням щось міняти в налагодженому навчальному процесі; відсутністю знань про діалогічні методи навчання та умінь, пов’язаних з їх використанням; страхом втратити свій викладацький авторитет.

Ураховувалося, що значні зусилля потрібно спрямувати на усунення виявлених утруднень викладачів, причини яких можна узагальнити таким чином: 1) брак знань про професійне спілкування; 2) психологічні бар'єри; 3) відсутність умінь і навичок діалогічного спілкування; 4) відсутність організаторських умінь; 5) закритість для нових ідей і методів; 6) авторитаризм та безапеляційність.

На основі аналізу встановлених утруднень педагогів вищої аграрної школи у зверненні до діалогічних методів навчання припускаємо, що для створення внутрішньовишівських умов для активного використання діалогічних методів викладання важливими є такі сфери впливу, як-от:

- $\quad$ мотиваційна сфера (формування позитивного ставлення до використання діалогу в навчанні, інтересу до набуття знань про діалог, прагнення до творчості у професійній діяльності, намагання саморозвиватися і самореалізовуватися в діалогічній взаємодії зі студентами);

когнітивна сфера (сприяння розвитку уваги, пам'яті, мислення; формування вміння здійснювати вплив на відповідні якості і здібності студентів; навчання тому, як позбутися «дисонансу» у відносинах зі студентами з різним рівнем розвитку когнітивних умінь, формування уміння пробуджувати у студентів сумніви і спонукати їх до творчості);

почуттєва сфера (розвиток толерантності; вдосконалення самоконтролю, особливо у стресових ситуаціях; тренування вміння «читати співрозмовника», відчувати його емоційний стан; сприяння розвитку емпатії);

діяльнісна сфера (формування правил поведінки у певних діалогових ситуаціях; розвиток комунікативних умінь і навичок; сприяння створенню власної професійної поведінки і виробленню стратегії дії для розв'язання педагогічних задач за звичних умов та пошуку творчих рішень у нестандартних педагогічних ситуаціях).

Отже, для успішного здійснення підготовки викладачів до діалогізації педагогічного процесу необхідно розв'язати такі завдання: а) провести психолого-педагогічну підготовку викладачів до активної діалогової взаємодії зі студентами; б) здійснити теоретико-методичну підготовку з питань сутності та особливостей процесу формування культури професійного спілкування у вищих аграрних навчальних закладах; в) сприяти розвитку педагогічної техніки; г) тренувати уміння і навички діалогічного спілкування; д) розвивати організаційні уміння; е) підвищити рівень мовної і мовленнєвої культури.

Уважаємо, що для розв'язання цих завдань доцільно проводити психолого-педагогічну підготовку викладачів до активної діалогової взаємодії зі студентами у формі психолого-педагогічного семінару. У нашому експерименті це був постійно діючий семінар «Діалог у навчанні». Його робота грунтувалася на певних принципах.

1. Принцип активної співучасті. Викладачі-учасники семінару дискутували й затверджували запропоновану програму семінару, вносили свої пропозиції щодо розгляду актуальних з їхньої точки зору питань, i, як наслідок, брали активну участь у роботі семінару.

2. Принции «навчатися вчитися». Парадоксальним $\epsilon$ такий факт: багато з тих, хто навчає інших, не вміє вчитися сам. Пропускаючи процес навчання «через себе», викладачі професійно вдосконалюються. Таким чином, відбувається розвиток окремих навичок та умінь, корекція хибних установок та уявлень, зростання рівня теоретико-методичної та педагогічно-практичної підготовки.

3. Приниип мультиплікації. Все засвоєне на семінарі не осідало «мертвим вантажем» у колі його учасників, а розповсюджувалося серед студентів. Нові ідеї знаходили безпосереднє й швидке втілення на заняттях у студентських аудиторіях.

4. Принции плюралізму. Схильності більшості викладачів до авторитарності протиставлялася рівноправність різних позицій. У ході роботи семінару відбувалися корінні зміни у свідомості викладачів, переосмислення ними уявлень про одноваріантність розв'язання певних ситуацій. Природним шляхом було досягнуто усвідомлення того, що різні думки щодо розв'язання однієї і тієї ж проблеми мають право на існування. 
5. Принцип особистої зацікавленості. Виходячи з власних потреб, мотивів, планів, кожен викладач ставив перед собою власну мету, яку він міг досягти за допомогою участі в семінарі. Саме особиста зацікавленість викладачів зробила семінар продуктивним і творчим.

Програма семінару була розроблена 3 урахуванням результатів ії обговорення з учасниками семінару і включала таке коло психолого-педагогічних питань: 1) шляхи досягнення зворотного зв'язку зі студентською аудиторією; 2) формування толерантного ставлення до різних особистостей і різних точок зору; 3) подолання психологічних бар'єрів у діалогічному спілкуванні (побоювання бути незрозумілим, хвилювання перед аудиторією, формування впевненості в собі); 4) способи подолання конфліктних ситуацій; 5) навчання володінню собою (гальмування негативних емоцій, агресії); 6) об'єктивація суб'єктивної інтерпретації повідомлень; 7) «читання» душевного стану партнера; 8) відкриття чужих «смислів»; 9) сприйняття особистості партнера як певної «самості»; 10) уникнення ситуацій маніпулювання собою; 11) типологія особистостей за способом сприйняття (візуали, аудіали, кінестетики); 12) подолання страхів і побоювань (постати перед аудиторією, перебувати в центрі уваги, поставити себе в незручне становище, виявити некомпетентність, забути деталі призначеної для повідомлення інформації, наштовхнутися на критику, зробити будь-яку помилку, наразитися на вороже ставлення); 13) адекватна поведінка у стресових ситуаціях; 14) формування уміння отримувати задоволення від навчального спілкування.

Організація й проведення семінару призначалися для набуття викладачами знань про сутність навчального діалогу та використання його у практиці ВНЗ, для усвідомлення ними переваг діалогічних методів навчання над традиційними. До теоретико-методичної проблематики семінару належать такі питання:

- сутність, структура і принципи побудови діалогу;

- характеристика різних видів навчального діалогу і можливості їх застосування;

- порівняльна характеристика діалогічного і монологічного спілкування в навчальному процесі;

- діалогічні методи навчання як методи особистісно зорієнтованої технології навчання;

- сутність і значення суб'єкт-суб'єктних взаємовідносин і суб'єкт-суб'єктної взаємодії між учасниками навчального процесу;

селективність уваги та способи привернення іiі до власної інформації (обгрунтування актуальності інформації; співвіднесення запропонованої інформації з власними установками і цінностями студентів; виділення новизни чи нових, неочікуваних, аспектів інформації; нестандартні способи повідомлення інформації тощо); уявлення про суб'єктивність сприйняття інформації;

- поняття про види активного слухання (оцінювальне, рефлективне, емпатичне);

- стилі спілкування («керівник», «старший товариш», «мотиватор»);

- вербальні і невербальні засоби спілкування.

Навчальне діалогічне спілкування приречене на невдачу, якщо викладач не володіє педагогічною технікою на належному рівні. Розглядаючи педагогічну техніку як комплекс знань, умінь і навичок, необхідних для чіткої і ефективної організації занять, уважаємо доцільним сконцентрували увагу на розвитку таких умінь i навичок, необхідних викладачеві для встановлення діалогічних взаємовідносин і досягнення діалогічної взаємодії зі студентським колективом:

- вміння керувати своєю увагою і увагою студентів;

- вміння визначати психологічний стан студента за зовнішніми ознаками і впливати на нього;

- вміння визначати темп своїх педагогічних дій;

- вміння демонструвати своє ставлення і свої почуття до педагогічній ситуації, усвідомлювати свій психологічний стан і керувати ним;

- володіння культурою мови і мовлення;

- володіння невербальними засобами спілкування;

- уміння застосовувати технічні засоби навчання;

- піклування про свій зовнішній вигляд і керування своїм фізичним станом;

- уміння відчувати комунікативний стан аудиторії;

- вміння досягати комунікативної єдності педагога і аудиторії.

Крім розвитку вище вказаних умінь та навичок педагогічної техніки, вважаємо за доцільне визначити й додатково розвивати ще кілька вмінь, дуже важливих для педагога як учасника навчального діалогічного спілкування. Такими, на нашу думку, є:

уміння створювати атмосферу доброзичливості; володіння засобами заохочення до навчального спілкування;

уміння виявляти емпатію;

- уміння швидко і адекватно реагувати на зміну педагогічної ситуації і перебігу діалогічного спілкування.

Становлення суб'єкт-суб'єктних відносин розуміємо як:

- наповнення навчальних відносин гуманним змістом;

- реальні, а не вдавані рівноправність і партнерство викладачів і студентів у навчальному діалозі; 
- виявлення взаємоповаги в поєднанні зі збереженням почуття власної гідності;

- $\quad$ зближення викладача і студента в навчальному процесі (рух назустріч один до одному);

- прагнення до взаєморозуміння й уникнення конфліктних ситуацій;

- $\quad$ визнання за іншою стороною права на власну позицію й помилку;

- відсутність бажання «перебудувати опонента під себе»;

- високий рівень духовного комфорту;

- взаємодія, співпраця і співтворчість усіх учасників навчального процесу.

Суб'єкт-суб'єктними у педагогіці прийнято називати рівноправні партнерські відносини. Їх існування $є$ визначальним для успішного функціонування навчального діалогу. У дослідженні виходимо з того, що сучасний викладач вищого навчального закладу освіти вже не $є$ тим, ким він був в авторитарній педагогіці. Він не стоїть «над студентом», не протистоїть йому, не нехтує його ініціативою, не ставиться до нього як до змушеного беззаперечно приймати форми і методи організації навчального процесу, не нав'язує йому власного бачення проблем професійної підготовки, враховує його інтереси, здібності і спрямування. Ефективною співпраця викладача і студента $є$ тоді, коли за кожним з них визнається право на власну думку, на сумніви у правильності думки викладача. Якщо ж організаційні, керівні й оцінювальні функції повністю виконуються викладачем, це призводить лише до формального сприйняття студентами «правил гри», а не їхньої активної участі у взаємодії, та оманливо-ілюзорного враження співпраці.

Продуктивне й ефективне застосування діалогу в навчальній роботі залежить від готовності до нього викладачів як однієї із основних ланок педагогічного процесу. Запропоновано програму психолого-педагогічного семінару для викладачів аграрних ВНЗ «Діалог у навчанні», мета якого підготовка викладачів до діалогізації педагогічного процесу, активізації їхньої взаємодії зі студентами, сприяння переосмисленню викладачами їхніх функцій у демократичній парадигмі вищої освіти і переходу від авторитарних позицій до партнерської співпраці зі студентами.

Актуальними напрямами подальшої роботи $€$ вивчення питань інтелектуальної взаємодії викладачів і студентів, реалізації міждисциплінарних зв'язків, залучення студентів до розв'язання проблемних питань, пов’язаних із майбутньою професійною діяльністю.

\section{Література}

1. Вербицкий А. А. Активное обучение в высшей школе: контекстный подход / А. А. Вербицкий. - М. : Высшая школа, 1991. - 206 с. 2. Гончаренко С. У. Український педагогічний словник / С. У. Гончаренко. - К. : Либідь, 1997. - 376 с. 3. Кларин М. В. Инновационные модели учебного процесса в современной зарубежной педагогике : автореф. дис. ... докт. пед. наук: 13.00 .01 / М. В. Кларин. - М., 1994. - 40 с. 4. Ковалёв Г. А. Психология познания людьми друг друга / Г. А. Ковалёв // Вопросы психологии. - 1983. - №1. - С. 112-118. 5. Педагогічна майстерність: [підручник] / I. А. Зязюн, Л. В. Крамущенко, І. Ф. Кривонос та ін.; [за ред. І. А. Зязюна]. - К. : Вища школа, 2004. - 422 с. 